\title{
Determination of Isotopic Abundance Ratio of Biofield Energy Treated 1,4-Dichlorobenzene Using Gas Chromatography-Mass Spectrometry (GC-MS)
}

\author{
Mahendra Kumar Trivedi ${ }^{1}$, Alice Branton ${ }^{1}$, Dahryn Trivedi ${ }^{1}$, Gopal Nayak ${ }^{1}$, Kalyan Kumar Sethi ${ }^{2}$, \\ Snehasis Jana ${ }^{2, *}$ \\ ${ }^{1}$ Trivedi Global Inc., Henderson, NV, USA \\ ${ }^{2}$ Trivedi Science Research Laboratory Pvt. Ltd., Bhopal, Madhya Pradesh, India
}

Email address:

publication@trivedisrl.com (S. Jana)

${ }^{*}$ Corresponding author

\section{To cite this article:}

Mahendra Kumar Trivedi, Alice Branton, Dahryn Trivedi, Gopal Nayak, Kalyan Kumar Sethi, Snehasis Jana. Determination of Isotopic Abundance Ratio of Biofield Energy Treated 1,4-Dichlorobenzene Using Gas Chromatography-Mass Spectrometry (GC-MS). Modern Chemistry. Vol. 4, No. 3, 2016, pp. 30-37. doi: 10.11648/j.mc.20160403.11

Received: May 10, 2016; Accepted: June 25, 2016; Published: July 13, 2016

\begin{abstract}
The objective of the current study was to evaluate the effect of biofield energy treatment on the isotopic abundance ratios of $\mathrm{P}_{\mathrm{M}+1} / \mathrm{P}_{\mathrm{M}}, \mathrm{P}_{\mathrm{M}+2} / \mathrm{P}_{\mathrm{M}}, \mathrm{P}_{\mathrm{M}+3} / \mathrm{P}_{\mathrm{M}}$ and $\mathrm{P}_{\mathrm{M}+4} / \mathrm{P}_{\mathrm{M}}$ in $p$-DCB using gas chromatography-mass spectrometry (GC-MS). The $p$-DCB was divided into two parts - one part was control sample, and another part was considered as the treated sample which was subjected to biofield energy treatment (The Trivedi Effect ${ }^{\mathbb{B}}$ ). T1, T2, T3, and T4 were referred the biofield treated $p$-DCB having analyzed at different time intervals. The GC-MS analysis of both the control and biofield treated $p$-DCB indicated the presence of the parent molecular ion peak at $m / z 146$ along with four major fragmentation peaks at $m / z 111,75,55$ and 50 . The relative peak intensities of the fragmented ions in the biofield treated $p$-DCB were notably changed as compared to the control sample with respect to the time. The isotopic abundance ratio analysis using GC-MS revealed that the isotopic abundance ratio of $\mathrm{P}_{\mathrm{M}+1} / \mathrm{P}_{\mathrm{M}}$ at T1, T2, T3, and T4 (biofield energy treated $p$-DCB) was significantly increased by $10.87,83.90,225.16$, and $241.15 \%$, respectively as compared to the control sample. Consequently, the percentage change in the isotopic abundance ratio of $\mathrm{P}_{\mathrm{M}+2} / \mathrm{P}_{\mathrm{M}}$ at $\mathrm{T} 1, \mathrm{~T} 2$, and T3 (biofield energy treated $p$-DCB) was enhanced by $4.55,9.49$, and $1.80 \%$, respectively as compared to the control sample. Beside these, another two isotopic molecular ion peaks at $\mathrm{m} / \mathrm{z} 149$ and 150 were found in the GS-MS spectra due to arise from the contributions of various combinations of ${ }^{2} \mathrm{H},{ }^{13} \mathrm{C}$, and ${ }^{37} \mathrm{Cl}$. The isotopic abundance ratios of $\mathrm{P}_{\mathrm{M}+3} / \mathrm{P}_{\mathrm{M}}$ in biofield energy treated sample at T1, T2, T3, and T4 was significantly increased by $15.14,82.57,192.43$, and $218.31 \%$, respectively as compared to the control sample. Similarly, the $\mathrm{P}_{\mathrm{M}+4} / \mathrm{P}_{\mathrm{M}}$ in biofield energy treated sample at T1, T2, T3, and T4 was significantly increased by $13.80,86.66,186.13$, and $204.29 \%$, respectively as compared to the control sample. Overall, the isotopic abundance ratios of $\mathrm{P}_{\mathrm{M}+1} / \mathrm{P}_{\mathrm{M}}\left({ }^{2} \mathrm{H} /{ }^{1} \mathrm{H}\right.$ or ${ }^{13} \mathrm{C} /{ }^{12} \mathrm{C}$ ), $\mathrm{P}_{\mathrm{M}+2} / \mathrm{P}_{\mathrm{M}}\left({ }^{37} \mathrm{Cl} /{ }^{35} \mathrm{Cl}\right.$ ), for $\mathrm{P}_{\mathrm{M}+3} / \mathrm{P}_{\mathrm{M}}$ and $\mathrm{P}_{\mathrm{M}+4} / \mathrm{P}_{\mathrm{M}}$ (the probable combinations of ${ }^{2} \mathrm{H} /{ }^{1} \mathrm{H},{ }^{13} \mathrm{C} /{ }^{12} \mathrm{C}$, and ${ }^{37} \mathrm{Cl} /{ }^{35} \mathrm{Cl}$ ) were significantly enhanced in the biofield energy treated $p$-DCB. The biofield treated $p$-DCB has shown improved isotopic abundance ratios that might have altered the physicochemical properties, thermal properties and rate of reaction. Biofield treated $p$-DCB might be useful in pharmaceutical and chemical industries as intermediates during the manufacturing of pharmaceuticals and chemicals by monitoring the rate of chemical reaction.
\end{abstract}

Keywords: Biofield Energy Treatment, The Trivedi Effect ${ }^{\circledR}, 1,4-$ Dichlorobenzene, Gas Chromatography-Mass Spectrometry, Isotopic Abundance

\section{Introduction}

1,4-Dichlorobenzene (para-dichlorobenzene or $p$-DCB:
$\mathrm{C}_{6} \mathrm{H}_{4} \mathrm{Cl}_{2}$ ) is a halogenated organic compound, used for pesticide, disinfectant, deodorant, and a precursor to other chemicals [1-3]. Moreover, it is used as a chemical intermediate for the manufacture of dyes, agrochemicals, 
pharmaceuticals, plastics, polymers, and other organic synthesis [3]. Acute exposure via inhalation in humans results in irritation of the skin, throat, and eyes [4]. Animal studies have reported the effects of oral exposure to the blood, liver, and kidney has moderate toxicity [5]. Nowadays chlorobenzenes are widely distributed in the environment due to point pollution sources as well as diffusive contamination [6]. It is combustible, incompatible with oxidizing agents, aluminium and its alloys and some plastics [3]. The low flash point $\left(66^{\circ} \mathrm{C}\right)$ and low melting point $\left(53.5^{\circ} \mathrm{C}\right)$ limits its application [7], and this is one of the reasons for the health discomfort of personnel working with them such as headaches, nausea, vomiting, numbness, and sleepiness [8, 9]. Thus, improvement in the physicochemical and thermal properties (i.e. stability) of $p$-DCB is one of the important properties which determine the future of the many finished products.

The stable isotope ratio analysis is a molecular tool widely used in several fields such as geographical, agricultural, food authenticity, biochemistry, metabolism, medical research, sports, etc. [10-13]. Similarly, it has great value in the early diagnosis and evaluation of therapies [14]. The isotopic abundance of a molecule can be altered in different ways, such as chemical reactions, etc. [11, 15]. Mr. Trivedi's biofield energy treatment has the remarkable capability to alter the isotopic abundance ratios of various compounds [1620]. For e.g. the stable isotopic abundance ratio of $\mathrm{P}_{\mathrm{M}+2} / \mathrm{P}_{\mathrm{M}}$ $\left({ }^{18} \mathrm{O} /{ }^{16} \mathrm{O}\right)$ in 2-naphthol was increased after biofield energy treatment up to $163.24 \%$ [16]. The isotopic abundance ratios of $\mathrm{P}_{\mathrm{M}+1} / \mathrm{P}_{\mathrm{M}}\left({ }^{2} \mathrm{H} /{ }^{1} \mathrm{H}\right.$ or $\left.{ }^{13} \mathrm{C} /{ }^{12} \mathrm{C}\right)$ in biofield treated toluene and $p$-xylene were significantly increased by 531.61 and $134.34 \%$, respectively [17]. Biofield energy is an electromagnetic field existed in the surround of the human body [21-23]. The energy can be harnessed from the universe and then, it can be applied by the healing practitioner on living or non-living objects to achieve the alterations in the characteristic properties. The application of The Trivedi Effect $^{\circledR}$ has gained significantly scientific attention in the field of materials science [24, 25], agriculture [26, 27], biotechnology [28, 29], pharmaceuticals [30, 31], and medical sciences $[32,33]$.

The mass spectrometry (MS) technique is the primary choice for the isotope ratio analysis [34]. The conventional scanning technique such as gas chromatography-mass spectrometry (GC-MS) can perform isotope ratio measurement at low micro molar concentration levels with sufficient precision if the molar isotope enrichment levels of the molecule are above $0.1 \%$. Several literatures described that the peak height (i.e. relative abundance) in the mass spectra is directly proportional to the relative isotopic abundance of the sample [34-37].

Recently, it has been reported that Mr. Trivedi's biofield energy treatment (The Trivedi Effect ${ }^{\circledR}$ ) has the astounding capability to change in the physicochemical and thermal properties of $p$-DCB such as reduced crystallite size, and enhanced thermal stability that might affect the rate of chemical reaction [24]. Based on all these aspects, the current study was designed to investigate the isotopic abundance ratios of $\mathrm{P}_{\mathrm{M}+1} / \mathrm{P}_{\mathrm{M}}, \mathrm{P}_{\mathrm{M}+2} / \mathrm{P}_{\mathrm{M}}, \mathrm{P}_{\mathrm{M}+3} / \mathrm{P}_{\mathrm{M}}$ and $\mathrm{P}_{\mathrm{M}+4} / \mathrm{P}_{\mathrm{M}}$ in biofield energy treated $p$-DCB using GC-MS technique.

\section{Materials and Methods}

\subsection{Chemicals and Reagents}

p-DCB was purchased from S. D. Fine Chemicals Pvt. Ltd., India All the other chemicals used in this experiment were analytical grade purchased from local vendors.

\subsection{Biofield Energy Treatment Strategies}

$p$-DCB was divided into two parts; one was kept as a control (un-treated) while another part was exposed to biofield energy treatment (The Trivedi Effect $\left.{ }^{(}\right)$and coded as treated sample. The sample for the treatment group was handed over to Mr. Trivedi for biofield treatment. Mr. Trivedi provided the biofield energy treatment through his unique energy transmission process to the treated group for 5 minutes. The treated sample was returned in the similar sealed condition for further analysis.

\subsection{Methods of GC-MS Analysis}

The GC-MS analysis was performed with the help of Perkin Elmer/auto system XL with Turbo mass, USA. For GC-MS analysis, the biofield energy treated sample was analyzed at the different time point of day $0,11,16$, and, 23 and denoted as T1, T2, T3, and T4, respectively. The spectrum obtained in the form of \% relative abundance $v s$. mass to charge ratio $(\mathrm{m} / \mathrm{z})$, which was known as mass spectrum.

The natural abundance of each isotope can be predicted from the comparison of the height of the isotope peak with respect to the base peak, i.e. relative abundance in the mass spectra [34]. The value of the natural isotopic abundance of the some elements are obtained from several literatures and presented in Table $1[34,37]$.

Table 1. The isotopic composition (the natural isotopic abundance) of the elements.

\begin{tabular}{lllll}
\hline Element $(\boldsymbol{A})$ & Symbol & Mass & \% Natural Abundance & $\boldsymbol{A + 1 ~ F a c t o r ~}$ \\
\hline Hydrogen & ${ }^{1} \mathrm{H}$ & 1 & 99.9885 & $\boldsymbol{A + 2}$ Factor \\
& ${ }^{2} \mathrm{H}$ & 2 & 0.0115 & $0.015 \mathrm{n}_{\mathrm{H}}$ \\
Carbon & ${ }^{12} \mathrm{C}$ & 12 & 98.892 & $1.1 \mathrm{n}_{\mathrm{C}}$ \\
& ${ }^{13} \mathrm{C}$ & 13 & 1.108 & \\
Oxygen & ${ }^{16} \mathrm{O}$ & 16 & 99.762 & $0.04 \mathrm{n}_{\mathrm{O}}$ \\
& ${ }^{17} \mathrm{O}$ & 17 & 0.038 & \\
\hline
\end{tabular}




\begin{tabular}{llllll}
\hline Element $(\boldsymbol{A})$ & Symbol & Mass & \% Natural Abundance & $\boldsymbol{A}+\mathbf{1}$ Factor & $\boldsymbol{A}+\mathbf{2}$ Factor \\
\hline \multirow{3}{*}{ Nitrogen } & ${ }^{18} \mathrm{O}$ & 18 & 0.200 & & $0.20 \mathrm{n}_{\mathrm{O}}$ \\
& ${ }^{14} \mathrm{~N}$ & 14 & 99.60 & $0.40 \mathrm{n}_{\mathrm{N}}$ & \\
Chlorine & 15 & 0.40 & & $32.50 \mathrm{n}_{\mathrm{Cl}}$ \\
& ${ }^{15} \mathrm{~N}$ & 35 & 75.78 & \\
\hline
\end{tabular}

$A$ : Element; n: no of $\mathrm{H}, \mathrm{C}, \mathrm{O}, \mathrm{Cl}$, etc.

The following method was used for calculating the isotopic abundance ratio:

$\mathrm{P}_{\mathrm{M}}$ stands for the relative peak intensity of the parent molecular ion $\left[\mathrm{M}^{+}\right]$expressed in percentage. In other way, it indicates the probability to have $A$ element (for $e . g .{ }^{12} \mathrm{C},{ }^{1} \mathrm{H}$, ${ }^{16} \mathrm{O},{ }^{14} \mathrm{~N}$, etc.) contributions to the mass of the parent molecular ion $\left[\mathrm{M}^{+}\right]$.

$\mathrm{P}_{\mathrm{M}+1}$ represents the relative peak intensity of the isotopic molecular ion $\left[(\mathrm{M}+1)^{+}\right]$expressed in percentage

$=\left(\right.$ no. of $\left.{ }^{13} \mathrm{C} \times 1.1 \%\right)+\left(\right.$ no. of $\left.{ }^{15} \mathrm{~N} \times 0.40 \%\right)+\left(\right.$ no. of ${ }^{2} \mathrm{H} \mathrm{x}$ $0.015 \%)+\left(\right.$ no. of $\left.{ }^{17} \mathrm{O} \times 0.04 \%\right)$

i.e. the probability to have $A+1$ element (for e.g. ${ }^{13} \mathrm{C},{ }^{2} \mathrm{H}$,

${ }^{15} \mathrm{~N}$, etc.) contributions to the mass of the isotopic molecular ion $\left[(\mathrm{M}+1)^{+}\right]$

$\mathrm{P}_{\mathrm{M}+2}$ represents the relative peak intensity of the isotopic molecular ion $\left[(\mathrm{M}+2)^{+}\right]$expressed in the percentage

$=\left(\right.$ no. of $\left.{ }^{18} \mathrm{O} \times 0.20 \%\right)+\left(\right.$ no. of $\left.{ }^{37} \mathrm{Cl} \times 32.50 \%\right)$

i.e the probability to have $A+2$ element (for e.g. ${ }^{18} \mathrm{O},{ }^{37} \mathrm{Cl}$,

${ }^{34} \mathrm{~S}$, etc.) contributions to the mass of isotopic molecular ion $\left[(\mathrm{M}+2)^{+}\right]$

Isotopic abundance ratio for $A+1$ element $=\mathrm{P}_{\mathrm{M}+1} / \mathrm{P}_{\mathrm{M}}$

Similarly, isotopic abundance ratio for $A+2$ element $=$ $\mathrm{P}_{\mathrm{M}+2} / \mathrm{P}_{\mathrm{M}}$

Percentage $(\%)$ change in isotopic abundance ratio = $\left.\left[\left(\mathrm{IAR}_{\text {Treated }}-\mathrm{IAR}_{\text {Control }}\right) / \mathrm{IAR}_{\text {Control }}\right) \times 100\right]$

Where, $\mathrm{IAR}_{\text {Treated }}=$ isotopic abundance ratio in the treated sample and $\mathrm{IAR}_{\text {Control }}=$ isotopic abundance ratio in the control sample.

\section{Results and Discussions}

The mass spectrum obtained by the GC-MS analysis for the control and biofield energy treated $p$-DCB $\left(\mathrm{C}_{6} \mathrm{H}_{4} \mathrm{Cl}_{2}\right)$ in the positive-ion mode were shown in Figure 1 and 2, respectively. Figure 1 indicated the presence of the parent molecular ion peak of $p$-DCB at $m / z 146$ (calculated 145.97 for $\mathrm{C}_{6} \mathrm{H}_{4} \mathrm{Cl}_{2}{ }^{+}$) at the retention time $\left(\mathrm{R}_{\mathrm{t}}\right)$ of $7.23 \mathrm{~min}$ along with four major fragmented peaks that were well matched with the literature [38]. The major fragmentation peaks at $\mathrm{m} / \mathrm{z}$ $111,75,55$ and 50 were due to the fragmentation of $p$-DCB into $\mathrm{C}_{6} \mathrm{H}_{4} \mathrm{Cl}^{+}, \mathrm{C}_{6} \mathrm{H}_{3}{ }^{+}, \mathrm{C}_{4} \mathrm{H}_{7}^{+}$, and $\mathrm{C}_{4} \mathrm{H}_{2}^{+}$, respectively. The biofield treated sample exhibited the parent molecular ion peaks $\left(\mathrm{C}_{6} \mathrm{H}_{4} \mathrm{Cl}_{2}{ }^{+}\right)$at $\mathrm{m} / z 146$ at $\mathrm{R}_{\mathrm{t}}$ of $7.24,7.25,7.27$, and $7.33 \mathrm{~min}$ and were very close to the $\mathrm{R}_{\mathrm{t}}$ of the control sample. The biofield energy treated sample analyzed at different time intervals (T1, T2, T3, and T4) showed similar fragmentation pattern as control (Figure 2). Only, the relative peak intensities of the fragmented ions in biofield treated sample were significantly altered with respect to the time.
The molecule $p$-DCB comprises several atoms of $\mathrm{H}, \mathrm{C}$, and $\mathrm{Cl}$. Calculating the relative abundances for the isotopic contributions to the peaks in various ion clusters at low $\mathrm{m} / \mathrm{z}$ discrimination will reflect the contributions of several different isotopes to the same peak. [34, 37, 39, 40]. The most intense peak $\mathrm{P}_{\mathrm{M}}$ in this cluster was at $m / z 146$, and its size is determined solely by the most abundant elemental composition which is defined as ' $100 \%$ '.

$\mathrm{P}_{\mathrm{M}+1}$ and $\mathrm{P}_{\mathrm{M}+2}$ can be calculated theoretically according to the method described in the materials and method.

$\mathrm{P}\left({ }^{13} \mathrm{C}\right)=\left[(6 \times 1.1 \%) \times 100 \%\right.$ (the actual size of the $\mathrm{M}^{+}$ peak) $] / 100 \%=6.6 \%$

$\mathrm{P}\left({ }^{2} \mathrm{H}\right)=[(4 \times 0.015 \%) \times 100 \%] / 100 \%=0.06 \%$

Thus, $\mathrm{P}_{\mathrm{M}+1}$ i.e. ${ }^{13} \mathrm{C}$ and ${ }^{2} \mathrm{H}$ contributions from $\left(\mathrm{C}_{6} \mathrm{H}_{4} \mathrm{Cl}_{2}{ }^{+}\right)$to $\mathrm{m} / \mathrm{z} 147$ is $6.66 \%$.

$\mathrm{P}\left({ }^{37} \mathrm{Cl}_{2}\right)=[(2 \times 32.5 \%) \times 100 \%] / 100 \%=65.0 \%$

So, $\mathrm{P}_{\mathrm{M}+2}$ i.e. ${ }^{37} \mathrm{Cl}$ contributions from $\left(\mathrm{C}_{6} \mathrm{H}_{4} \mathrm{Cl}_{2}{ }^{+}\right)$to $\mathrm{m} / z 148$ is $65.0 \%$.

Beside these, another two isotopic molecular ion peaks at $\mathrm{m} / \mathrm{z} 149$ and 150 were found in the GS-MS spectra due to the presence of two chlorine atoms in the molecule. $\mathrm{P}_{\mathrm{M}+3}$ was obtained from the many possible combinations like ${ }^{13} \mathrm{C}^{37} \mathrm{Cl}$, ${ }^{2} \mathrm{H}^{37} \mathrm{Cl}$, etc. contributions from $\left(\mathrm{C}_{6} \mathrm{H}_{4} \mathrm{Cl}_{2}{ }^{+}\right)$to $\mathrm{m} / \mathrm{z} 149$. Similarly, the $\mathrm{P}_{\mathrm{M}+4}$ was occurring due to many possible combinations like ${ }^{13} \mathrm{C}^{2} \mathrm{H}^{37} \mathrm{Cl},{ }^{37} \mathrm{Cl}_{2},{ }^{13} \mathrm{C}_{2}{ }^{37} \mathrm{Cl},{ }^{2} \mathrm{H}^{37} \mathrm{Cl}$, etc. contributions from $\left(\mathrm{C}_{6} \mathrm{H}_{4} \mathrm{Cl}_{2}^{+}\right)$to $\mathrm{m} / z 150$.

It has been found that statistically, the coincidental of both carbons being ${ }^{13} \mathrm{C}$ is approximately 1 in 10,000 [41-43]. The deuterium did not contribute much any of the $\mathrm{m} / \mathrm{z}$ ratios in natural $p$-DCB as the natural abundance of deuterium is too small relative to the natural abundances of isotopes of carbon and chlorine. Hence, ${ }^{13} \mathrm{C}$ and ${ }^{37} \mathrm{Cl}$ have the major contributions from $\left(\mathrm{C}_{6} \mathrm{H}_{4} \mathrm{Cl}_{2}{ }^{+}\right)$to $\mathrm{m} / \mathrm{z} 147,148,149$, and 150 [41-44].

$\mathrm{P}_{\mathrm{M}}, \mathrm{P}_{\mathrm{M}+1}, \mathrm{P}_{\mathrm{M}+2}, \mathrm{P}_{\mathrm{M}+3} / \mathrm{P}_{\mathrm{M}}$ and $\mathrm{P}_{\mathrm{M}+4} / \mathrm{P}_{\mathrm{M}}$ for the control and biofield energy treated $p$-DCB at $m / z 147,148,149$, and 150 , respectively were achieved from the observed relative intensity of $\left[\mathrm{M}^{+}\right],\left[(\mathrm{M}+1)^{+}\right],\left[(\mathrm{M}+2)^{+}\right], \quad\left[(\mathrm{M}+3)^{+}\right]$, and $\left[(\mathrm{M}+4)^{+}\right]$peaks in the GC-MS spectra respectively and are shown in Table 2.

The percentage change in isotopic abundance ratios of $\mathrm{P}_{\mathrm{M}+1} / \mathrm{P}_{\mathrm{M}}, \mathrm{P}_{\mathrm{M}+2} / \mathrm{P}_{\mathrm{M}}, \mathrm{P}_{\mathrm{M}+3} / \mathrm{P}_{\mathrm{M}}$ and $\mathrm{P}_{\mathrm{M}+4} / \mathrm{P}_{\mathrm{M}}$ in the control and biofield treated $p$-DCB are presented in Table 2 and Figure 3. The isotopic abundance ratios in biofield energy treated $p$ DCB (T1-T4) were calculated comparing to the control sample using the mass spectrum (Table 2). The relative peak intensities of $\mathrm{P}_{\mathrm{M}+2}$ and $\mathrm{P}_{\mathrm{M}+4}$ was significantly larger than $\mathrm{P}_{\mathrm{M}+1}$ and $\mathrm{P}_{\mathrm{M}+3}$ due to the high influence of two chlorine atoms presented in $p$-DCB (Figure 1 and 2). 


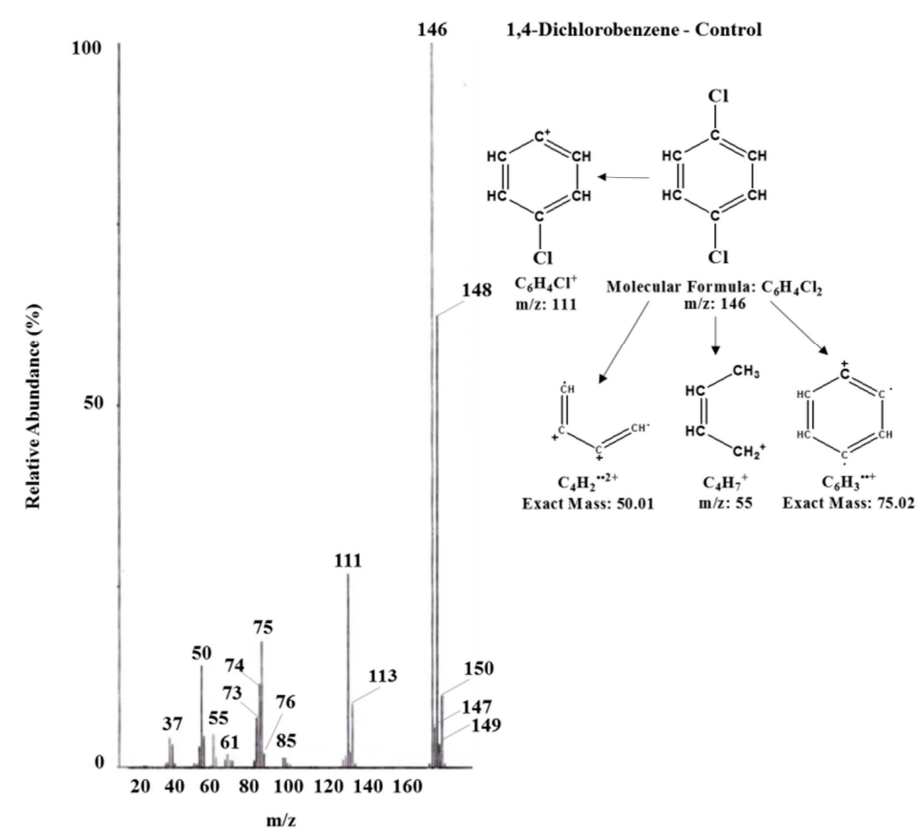

Figure 1. The GC-MS spectrum and different proposed fragmentations of control sample of $p-D C B$.
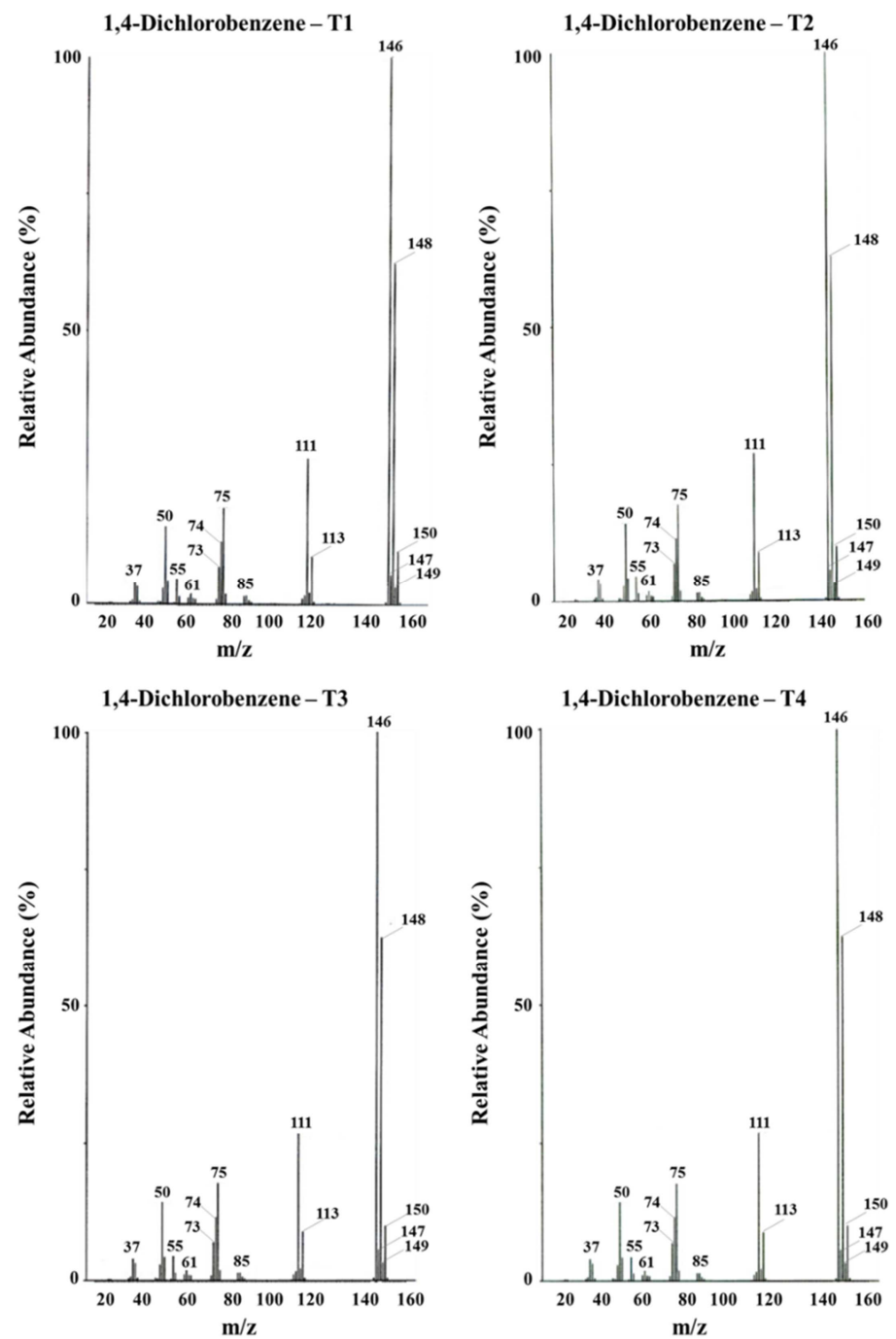

Figure 2. The GC-MS spectra of biofield energy treated p-DCB analyzed at the different time points (T1, T2, T3, and T4). 
Table 2. Results of isotopic abundance ratios in control and biofield energy treated p-DCB.

\begin{tabular}{|c|c|c|c|c|c|}
\hline \multirow{2}{*}{ Parameter } & \multirow{2}{*}{ Control } & \multicolumn{4}{|c|}{ Treated } \\
\hline & & T1 & T2 & T3 & T4 \\
\hline $\mathrm{P}_{\mathrm{M}}$ at $m / z 146(\%)$ & 100 & 100 & 100 & 100 & 100 \\
\hline $\mathrm{P}_{\mathrm{M}+1}$ at $m / z 147(\%)$ & 9.38 & 10.40 & 17.25 & 30.50 & 32.00 \\
\hline $\mathrm{P}_{\mathrm{M}+1} / \mathrm{P}_{\mathrm{M}}$ & 0.0938 & 0.1040 & 0.1725 & 0.3050 & 0.3200 \\
\hline$\%$ Change of isotopic abundance ratio $\left(\mathrm{P}_{\mathrm{M}+1} / \mathrm{P}_{\mathrm{M}}\right)$ & & 10.87 & 83.90 & 225.16 & 241.15 \\
\hline $\mathrm{P}_{\mathrm{M}+2}$ at $m / z 148(\%)$ & 83.71 & 87.52 & 91.65 & 85.22 & 83.48 \\
\hline $\mathrm{P}_{\mathrm{M}+2} / \mathrm{P}_{\mathrm{M}}$ & 0.8371 & 0.8752 & 0.9165 & 0.8522 & 0.8348 \\
\hline$\%$ Change of isotopic abundance ratio $\left(\mathrm{P}_{\mathrm{M}+2} / \mathrm{P}_{\mathrm{M}}\right)$ & & 4.55 & 9.49 & 1.80 & -0.28 \\
\hline $\mathrm{P}_{\mathrm{M}+3}$ at $m / z 149(\%)$ & 5.68 & 6.54 & 10.37 & 16.61 & 18.08 \\
\hline $\mathrm{P}_{\mathrm{M}+3} / \mathrm{P}_{\mathrm{M}}$ & 0.0568 & 0.0654 & 0.1037 & 0.1661 & 0.1808 \\
\hline$\%$ Change of isotopic abundance ratio $\left(\mathrm{P}_{\mathrm{M}+3} / \mathrm{P}_{\mathrm{M}}\right)$ & & 15.14 & 82.57 & 192.43 & 218.31 \\
\hline $\mathrm{P}_{\mathrm{M}+4}$ at $m / z 150(\%)$ & 15.14 & 17.23 & 28.26 & 43.32 & 46.07 \\
\hline $\mathrm{P}_{\mathrm{M}+4} / \mathrm{P}_{\mathrm{M}}$ & 0.1514 & 0.1723 & 0.2826 & 0.4332 & 0.4607 \\
\hline$\%$ Change of isotopic abundance ratio $\left(\mathrm{P}_{\mathrm{M}+4} / \mathrm{P}_{\mathrm{M}}\right)$ & & 13.80 & 86.66 & 186.13 & 204.29 \\
\hline
\end{tabular}

T1, T2, T3, and T4: biofield energy treated sample analyzed at different time interval; M: mass of the parent molecule; $\mathrm{P}_{\mathrm{M}}$ : the relative peak intensity of the parent molecular ion $\left[\mathrm{M}^{+}\right] ; \mathrm{P}_{\mathrm{M}+1}$ : the relative peak intensity of the isotopic molecular ion $\left[(\mathrm{M}+1)^{+}\right] ; \mathrm{P}_{\mathrm{M}+2}$ : the relative peak intensity of the isotopic molecular ion $\left[(\mathrm{M}+2)^{+}\right], \mathrm{P}_{\mathrm{M}+3}$ : the relative peak intensity of the isotopic molecular ion $\left[(\mathrm{M}+3)^{+}\right], \mathrm{P}_{\mathrm{M}+4}$ : the relative peak intensity of the isotopic molecular ion $\left[(\mathrm{M}+4)^{+}\right]$.

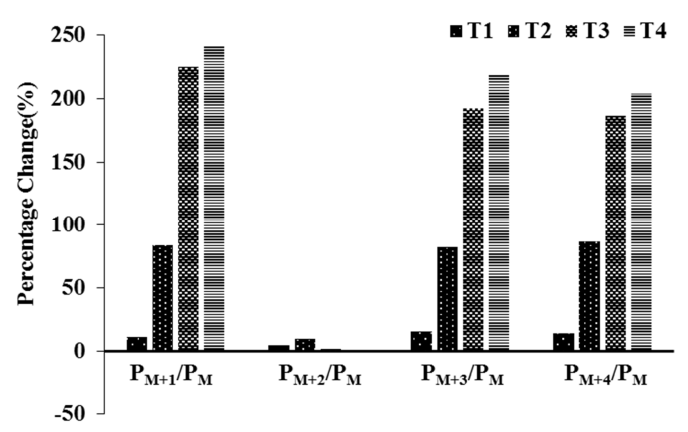

Figure 3. Percent change of the isotopic abundance ratios of $\left(P_{M+1}\right) / P_{M}$, $\left(P_{M+2}\right) / P_{M},\left(P_{M+3}\right) / P_{M}$ and $\left(P_{M+4}\right) / P_{M}$ compared to the control in $p-D C B$ after biofield energy treatment.

The GC-MS spectral analysis revealed that the isotopic abundance ratio of $\mathrm{PM}+1 / \mathrm{PM}$ in biofield energy treated sample at $\mathrm{T} 1, \mathrm{~T} 2, \mathrm{~T} 3$, and $\mathrm{T} 4$ was significantly increased by $10.87,83.90,225.16$, and $241.15 \%$, respectively in comparison to the control sample (Table 2). Consequently, the $\mathrm{P}_{\mathrm{M}+2} / \mathrm{P}_{\mathrm{M}}$ in biofield energy treated sample at $\mathrm{T} 1, \mathrm{~T} 2$, and $\mathrm{T} 3$ was increased by $4.55,9.49$, and $1.80 \%$, respectively in comparison to the control sample. On the contrary, the $\mathrm{P}_{\mathrm{M}+2} / \mathrm{P}_{\mathrm{M}}$ in biofield energy treated sample at $\mathrm{T} 4$ were slightly less (0.28) than the control sample (Table 2). The isotopic abundance ratio of $\mathrm{P}_{\mathrm{M}+3} / \mathrm{P}_{\mathrm{M}}$ in biofield energy treated sample at $\mathrm{T} 1, \mathrm{~T} 2, \mathrm{~T} 3$, and $\mathrm{T} 4$ was significantly increased by 15.14 , $82.57,192.43$, and $218.31 \%$, respectively in comparison to the control sample (Table 2). Similarly, the isotopic abundance ratio of $\mathrm{P}_{\mathrm{M}+4} / \mathrm{P}_{\mathrm{M}}$ in biofield energy treated sample at $\mathrm{T} 1, \mathrm{~T} 2, \mathrm{~T} 3$, and $\mathrm{T} 4$ was significantly increased by 13.80 , $86.66,186.13$, and $204.29 \%$, respectively in comparison to the control sample (Table 2). The Figure 3 clearly suggest that there was a different effect of the isotopic abundance ratios $\left(\mathrm{P}_{\mathrm{M}+1} / \mathrm{P}_{\mathrm{M}}, \mathrm{P}_{\mathrm{M}+3} / \mathrm{P}_{\mathrm{M}}\right.$, and $\left.\mathrm{P}_{\mathrm{M}+4} / \mathrm{P}_{\mathrm{M}}\right)$ in biofield energy treated samples with respect to the time. This indicated that these samples had the time dependent response. On the other hand, the isotopic abundance ratio of $\mathrm{P}_{\mathrm{M}+2} / \mathrm{P}_{\mathrm{M}}$ in treated sample showed different behaviour i.e. it was increased up to a certain period, then suddenly decreased. These results suggest that the biofield energy might have taken some time for the changes in the isotopic abundance ratio.

Replacement of the isotopic composition of the molecule significantly alters the vibrational energy $[45,46]$. The vibrational energy depends on the reduced mass $(\mu)$ for a diatomic molecule as shown in the below:

$$
\mathrm{E}_{0}=\frac{h}{4 \pi} \sqrt{\frac{f}{\mu}} \text { and reduced mass }(\mu)=\frac{m_{a} m_{b}}{m_{a}+m_{b}}
$$

Where, $E_{0}=$ the vibrational energy of a harmonic oscillator at absolute zero or zero point energy; $f=$ force constant

The reduced mass $(\mu)$ of some probable isotopic bonds was calculated and presented in Table 3. The result showed that $\mu$ of normal bond i.e. ${ }^{12} \mathrm{C}-{ }^{12} \mathrm{C}(\mu=6),{ }^{12} \mathrm{C}-{ }^{35} \mathrm{Cl}(\mu=8.94)$, and ${ }^{1} \mathrm{H}^{12} \mathrm{C}(\mu=0.92)$ were increased in case of heavier isotopic bond i.e. ${ }^{13} \mathrm{C}-{ }^{12} \mathrm{C}(\mu=6.24),{ }^{12} \mathrm{C}-{ }^{37} \mathrm{Cl}(\mu=9.06),{ }^{13} \mathrm{C}$ ${ }^{35} \mathrm{Cl}(\mu=9.48),{ }^{1} \mathrm{H}-{ }^{13} \mathrm{C}(\mu=0.93),{ }^{13} \mathrm{C}-{ }^{37} \mathrm{Cl}(\mu=9.62)$, and ${ }^{2} \mathrm{H}-{ }^{12} \mathrm{C}$ $(\mu=1.71)$. As per the literature, the heavier isotopic molecules have lower diffusion velocity, mobility, evaporation rate, thermal decomposition and reaction rate, but having higher binding energy than lighter molecules [4548]. The biofield energy treated $p$-DCB have the higher isotopic abundance ratios. Therefore, after biofield energy treatment, bond strength, stability, and binding energy of $p$ DCB molecule might be increased due to the higher effective internal mass $(\mu)$.

Table 3. Possible isotopic bonds in p-DCB.

\begin{tabular}{lll}
\hline Isotopes bond & Isotope type & Reduced mass $(\mu)\left(\mathbf{m}_{\mathrm{A}} \cdot \mathbf{m}_{\mathrm{B}} /\left(\mathbf{m}_{\mathrm{A}}+\mathbf{m}_{\mathrm{B}}\right)\right.$ \\
\hline${ }^{12} \mathrm{C}-{ }^{12} \mathrm{C}$ & Lighter & 6.00 \\
${ }^{13} \mathrm{C}-{ }^{12} \mathrm{C}$ & Heavier & 6.24 \\
${ }^{1} \mathrm{H}-{ }^{-2} \mathrm{C}$ & Lighter & 0.92 \\
${ }^{1} \mathrm{H}-{ }^{13} \mathrm{C}$ & Heavier & 0.93 \\
${ }^{2} \mathrm{H}-{ }^{-2} \mathrm{C}$ & Heavier & 1.71 \\
${ }^{12} \mathrm{C}-{ }^{35} \mathrm{Cl}$ & Lighter & 8.94 \\
${ }^{13} \mathrm{C}-{ }^{35} \mathrm{Cl}$ & Heavier & 9.48 \\
${ }^{12} \mathrm{C}-{ }^{37} \mathrm{Cl}$ & Heavier & 9.06 \\
${ }^{13} \mathrm{C}-{ }^{37} \mathrm{Cl}$ & Heavier & 9.62 \\
\hline
\end{tabular}

$\mathrm{m}_{\mathrm{A}}$ : mass of atom $\mathrm{A} ; \mathrm{m}_{\mathrm{B}}$ : mass of atom $\mathrm{B}$, here $\mathrm{A}$ and $\mathrm{B}$ may be $\mathrm{C}$ or $\mathrm{H}$ or $\mathrm{Cl}$. 
The isotopic abundance ratios of $\mathrm{P}_{\mathrm{M}+1} / \mathrm{P}_{\mathrm{M}}\left({ }^{2} \mathrm{H} /{ }^{1} \mathrm{H}\right.$ or $\left.{ }^{13} \mathrm{C} /{ }^{12} \mathrm{C}\right), \quad \mathrm{P}_{\mathrm{M}+2} / \mathrm{P}_{\mathrm{M}}\left({ }^{37} \mathrm{Cl} /{ }^{35} \mathrm{Cl}\right), \quad \mathrm{P}_{\mathrm{M}+3} / \mathrm{P}_{\mathrm{M}}$ and $\mathrm{P}_{\mathrm{M}+4} / \mathrm{P}_{\mathrm{M}}$ (the probable combinations of ${ }^{2} \mathrm{H} /{ }^{1} \mathrm{H},{ }^{13} \mathrm{C} /{ }^{12} \mathrm{C}$, and ${ }^{37} \mathrm{Cl} /{ }^{35} \mathrm{Cl}$ ) in the biofield treated $p$-DCB were significantly increased in comparison to the control. The recent physics Noble prize winners explained that the neutrinos change identities which are only possible if the neutrinos possess mass and have the ability to interchange their phase internally from one phase to another (change of flavour). Due to this, the neutrinos have the ability to interact with protons and neutrons in the nucleus. There was a close connection between neutrino and the isotope formation $[49,50]$. The biofield energy treatment responsible for the modification in the behaviour at atomic and molecular level by changing the neutron to proton ratio in the nucleus possibly through the introduction of neutrino particles. It was postulated that the changes in isotopic abundance were due to changes in nuclei possibly trough intervention of neutrinos. As biofield treated $p$-DCB had increased the stable isotopic abundance ratio, it might have altered physicochemical and thermal properties and reaction rate. Thus, the current findings are well associated with the previous results [24].

\section{Conclusions}

The current study inferred that biofield energy treatment has a remarkable capability for altering the isotopic abundance ratio in $p$-DCB. The gas chromatography-mass spectrometric (GC-MS) analysis of the both control and biofield energy treated sample showed the presence of the molecular ion peak at $\mathrm{m} / \mathrm{z} 146$ (calculated 145.97 for $\mathrm{C}_{6} \mathrm{H}_{4} \mathrm{Cl}_{2}{ }^{+}$) along with four major fragmented peaks at $\mathrm{m} / \mathrm{z}$ $111,75,55$ and 50. Only, the relative peak intensities of the fragmented ions in treated sample were different from the control sample. The isotopic abundance ratios analysis in $p$ DCB revealed that the isotopic abundance ratio of $\mathrm{P}_{\mathrm{M}+1} / \mathrm{P}_{\mathrm{M}}$ in biofield energy treated sample at T1, T2, T3, and T4 was significantly increased by $10.87,83.90,225.16$, and $241.15 \%$, respectively as compared to the control. Consequently, the isotopic abundance ratio of $\mathrm{P}_{\mathrm{M}+2} / \mathrm{P}_{\mathrm{M}}$ was enhanced in biofield energy treated sample at T1, T2, and T3 by $4.55,9.49$, and $1.80 \%$, respectively as compared to the control. Subsequently, the $\mathrm{P}_{\mathrm{M}+3} / \mathrm{P}_{\mathrm{M}}$ in biofield energy treated sample at T1, T2, T3, and T4 was significantly increased by $15.14,82.57,192.43$, and $218.31 \%$, respectively as compared to the control sample. Similarly, the isotopic abundance ratio of $\mathrm{P}_{\mathrm{M}+4} / \mathrm{P}_{\mathrm{M}}$ in biofield energy treated sample at $\mathrm{T} 1, \mathrm{~T} 2, \mathrm{~T} 3$, and T4 was significantly improved by $13.80,86.66,186.13$, and $204.29 \%$, respectively as compared to the control sample. It was observed that the isotopic abundance ratios of $\mathrm{P}_{\mathrm{M}+1} / \mathrm{P}_{\mathrm{M}}, \mathrm{P}_{\mathrm{M}+3} / \mathrm{P}_{\mathrm{M}}$, and $\mathrm{P}_{\mathrm{M}+4} / \mathrm{P}_{\mathrm{M}}$ in the biofield treated sample were increased gradually with respect to time. As biofield energy treated $p$-DCB had increased isotopic abundance ratio, it might have altered physicochemical and thermal properties, and rate of reaction than the control sample. Hence, biofield energy treated $p$-DCB could be advantageous in pharmaceutical and chemical industries as intermediates during the preparation of pharmaceuticals and chemicals by controlling the rate of chemical reaction.

\section{Abbreviations}

A: Element; GC-MS: Gas chromatography-mass spectrometry; m/z: Mass/charge; M: mass of the parent molecule; $\mathrm{P}_{\mathrm{M}}$ : the relative peak intensity of the parent molecular ion $\left[\mathrm{M}^{+}\right] ; \mathrm{P}_{\mathrm{M}+1}$ : the relative peak intensity of the isotopic molecular ion $\left[(\mathrm{M}+1)^{+}\right] ; \mathrm{P}_{\mathrm{M}+2}$ : the relative peak intensity of the isotopic molecular ion $\left[(\mathrm{M}+2)^{+}\right], \mathrm{P}_{\mathrm{M}+3}$ : the relative peak intensity of the isotopic molecular ion $\left[(\mathrm{M}+3)^{+}\right], \mathrm{P}_{\mathrm{M}+4}$ : the relative peak intensity of the isotopic molecular ion $\left[(\mathrm{M}+4)^{+}\right]$.

\section{Acknowledgements}

The authors would like to acknowledge the Sophisticated Instrumentation Centre for Applied Research and Testing SICART, Gujarat, India for providing the instrumental facility. We are very grateful for the support from Trivedi Science, Trivedi Master Wellness and Trivedi Testimonials in this research work

\section{References}

[1] Rossberg M, Lendle W, Pfleiderer G, Togel A, Dreher EL, Langer E, Rassaerts H, Kleinschmidt P, Strack H, Cook R, Beck U, Lipper KA, Torkelson TR, Löser E, Beutel KK, Mann T (2006) Chlorinated hydrocarbons. Ullmann's Encyclopedia of Industrial Chemistry. ( $7^{\text {th }}$ Edn), Wiley-VCH, Verlag, Germany.

[2] National Pesticide Information Center - Parachlorobenzene general fact sheet. Retrieved in 02 April 2016.

[3] Fahey DR, Ash CE (1991) Mechanism of poly ( $p$-phenylene sulfide) growth from $p$-dichlorobenzene and sodium sulphide. Macromolecules 24: 4242-4249.

[4] Agency for Toxic Substances and Disease Registry (ATSDR) (1998) Toxicological Profile for 1, 4-dichlorobenzene (Update). Public Health Service, U.S. Department of Health and Human Services, Atlanta, GA.

[5] U.S. Department of Health and Human Services (1993) Hazardous Substances Data Bank (HSDB, online database). National Toxicology Information Program, National Library of Medicine, Bethesda.

[6] Griebler C, Adrian L, Meckenstock RU, Richnow HH (2004) Stable carbon isotope fractionation during aerobic and anaerobic transformation of trichlorobenzene. FEMS Microbiol Ecol 48: 313-321.

[7] Mackinson FW, Stricoff RS, Partridge LJ, Little AD (1981) Occupational Health Guidelines for Chemical Hazards. DHHS (NIOSH) Publication No. 81-123, Washington, DC, U.S.

[8] Djohan D, Yu J, Connell D, Christensen E (2007) Health risk assessment of chlorobenzenes in the air of residential houses using probabilistic techniques. J Toxicol Environ Health A 70: 1594-1603. 
[9] Ogata M, Taguchi T, Hirota N, Shimada Y, Nakae S (1991) Quantitation of urinary chlorobenzene metabolites by HPLC: Concentrations of 4-chlorocatechol and chlorophenols in urine and of chlorobenzene in biological specimens of subjects exposed to chlorobenzene. Int Arch Occup Environ Health 63: 121-128.

[10] Winderl C, Penning H, von Netzer F, Meckenstock RU, Lueders T (2010) DNA-SIP identifies sulfate-reducing Clostridia as important toluene degraders in tar-oilcontaminated aquifer sediment. The ISME Journal 4: 13141325 .

[11] Muccio Z, Jackson GP (2009) Isotope ratio mass spectrometry. Analyst 134: 213-222.

[12] Ben-David M, Flaherty EA (2012) Stable isotopes in mammalian research: a beginner's guide. Journal of Mammalogy 93: 312-328.

[13] Scott, KM, Fox, G, Girguis PR (2011) Measuring isotope fractionation by autotrophic microorganisms and enzymes. Methods Enzymol 494: 281-299.

[14] Morgan JLL, Skulan JL, Gordon GW, Romaniello SJ, Smith SM, Anbar AD (2012) Rapidly assessing changes in bone mineral balance using natural stable calcium isotopes. Proc Natl Acad Sci USA 109: 9989-9994.

[15] Gevaert $\mathrm{K}$, Impens $\mathrm{F}$, Ghesquière $\mathrm{B}$, Van Damme $\mathrm{P}$, Lambrechts A, Vandekerckhove J (2008) Stable isotopic labeling in proteomics. Proteomics 8: 4873-85.

[16] Trivedi MK, Branton A, Trivedi D, Nayak G, Saikia G, Jana S (2015) Evaluation of isotopic abundance ratio of naphthalene derivatives after biofield energy treatment using gas chromatography-mass spectrometry. American Journal of Applied Chemistry 3: 194-200.

[17] Trivedi MK, Branton A, Trivedi D, Nayak G, Saikia G, Jana S (2015) Isotopic abundance analysis of biofield treated benzene, toluene and $p$-xylene using gas chromatography-mass spectrometry (GC-MS). Mass Spectrom Open Access 1: 102.

[18] Trivedi MK, Branton A, Trivedi D, Nayak G, Saikia G, Jana S (2015) Influence of biofield energy treatment on isotopic abundance ratio in aniline derivatives. Mod Chem appl 3: 168.

[19] Trivedi MK, Branton A, Trivedi D, Nayak G, Saikia G, Jana S (2015) Quantitative determination of isotopic abundance ratio of ${ }^{13} \mathrm{C},{ }^{2} \mathrm{H}$, and ${ }^{18} \mathrm{O}$ in biofield energy treated ortho and meta toluic acid isomers. American Journal of Applied Chemistry 3: 217-223.

[20] Trivedi MK, Branton A, Trivedi D, Nayak G, Saikia G, Jana S (2015) Determination of isotopic abundance of ${ }^{2} \mathrm{H},{ }^{13} \mathrm{C},{ }^{18} \mathrm{O}$, and ${ }^{37} \mathrm{Cl}$ in biofield energy treated dichlorophenol isomers. Science Journal of Analytical Chemistry 4: 1-6.

[21] Hammerschlag R, Jain S, Baldwin AL, Gronowicz G, Lutgendor SK, Oschman JL, Yount GL (2012) Biofield research: A roundtable discussion of scientific and methodological issues. J Altern Complement Med 18: 10811086.

[22] Warber SL, Cornelio D, Straughn J, Kile G (2004) Biofield energy healing from the inside. J Altern Complement Med 10: 1107-1113.

[23] Rubik B (2002) The biofield hypothesis: Its biophysical basis and role in medicine. J Altern Complement Med 8: 703-717.
[24] Trivedi MK, Branton A, Trivedi D, Nayak G, Singh R, Jana S (2015) Physical, thermal and spectroscopic studies on biofield treated p-dichlorobenzene. Biochem Anal Biochem 4: 204.

[25] Trivedi MK, Nayak G, Patil S, Tallapragada RM, Latiyal O, Jana $S$ (2015) Impact of biofield treatment on atomic and structural characteristics of barium titanate powder. Ind Eng Manage 4: 166.

[26] Trivedi MK, Tallapragada RM, Branton A, Trivedi D, Nayak G, Mondal S, Jana S (2015) Impact of biofield energy treatment on soil fertility. Earth Sciences 4: 275-279.

[27] Trivedi MK, Tallapragada RM, Branton A, Trivedi D, Nayak G, Mondal S, Jana S (2015) Evaluation of biochemical marker - Glutathione and DNA fingerprinting of biofield energy treated Oryza sativa. American Journal of BioScience. 3: 243248 .

[28] Trivedi MK, Tallapragada RM, Branton A, Trivedi D, Nayak G, Mondal S, Jana S (2015) Antibiogram, biochemical reactions and genotyping characterization of biofield treated Staphylococcus aureus. American Journal of BioScience. 3: 212-220.

[29] Trivedi MK, Tallapragada RM, Branton A, Trivedi D, Nayak G, Bairwa K, Jana S (2015) Physical, thermal, and spectroscopic characterization of biofield energy treated potato micropropagation medium. American Journal of Bioscience and Bioengineering 3: 106-113.

[30] Trivedi MK, Patil S, Shettigar H, Bairwa K, Jana S (2015) Spectroscopic characterization of chloramphenicol and tetracycline: An impact of biofield. Pharm Anal Acta 6: 395.

[31] Trivedi MK, Patil S, Shettigar H, Bairwa K, Jana S (2015) Spectroscopic characterization of biofield treated metronidazole and tinidazole. Med Chem 5: 340-344.

[32] Trivedi MK, Patil S, Shettigar H, Mondal SC, Jana S (2015) The potential impact of biofield treatment on human brain tumor cells: A time-lapse video microscopy. J Integr Oncol 4: 141.

[33] Trivedi MK, Patil S, Shettigar H, Gangwar M, Jana S (2015) In vitro evaluation of biofield treatment on cancer biomarkers involved in endometrial and prostate cancer cell lines. J Cancer Sci Ther 7: 253-257.

[34] Smith RM (2004) Understanding Mass Spectra: A Basic Approach, Second Edition, John Wiley \& Sons, Inc, ISBN 0471-42949-X.

[35] Taylor PDP (1998) Isotopic compositions of the elements 1997. J Phys Chem Ref Data 27: 1275.

[36] Weisel CP, Park S, Pyo H, Mohan K, Witz G (2003) Use of stable isotopically labeled benzene to evaluate environmental exposures. J Expo Anal Environ Epidemiol 13: 393-402.

[37] Jürgen H. Gross Mass Spectrometry: A Textbook; Springer: Berlin, $2^{\text {nd }} E d n .2004$.

[38] Tsimeli K, Triantis TM, Dimotikali D, Hiskia A (2008) Development of a rapid and sensitive method for the simultaneous determination of 1, 2-dibromoethane, 1, 4dichlorobenzene and naphthalene residues in honey using HSSPME coupled with GC-MS. Anal Chim Acta 617: 64-71.

[39] Gordon J (1998) Inside informatics, cambridgesoft. com Article ID: Isotopic Abundance. 
[40] Johnstone RAW, Rose ME (1996) Mass Spectrometry for Chemists and Biochemists, $2^{\text {nd }}$ Edition. Cambridge university press.

[41] http://www.chemguide.co.uk/analysis/masspec/mplus1.html.

[42] http://www.chemguide.co.uk/analysis/masspec/mplus2.html.

[43] http://www.chem.uoa.gr/applets/AppletMS/Appl_Ms2.html.

[44] Wieser ME (2006) Atomic weights of the elements 2005. Pure Appl Chem 78: 2051-2066.

[45] Vanhaecke F, Kyser K (2012) Isotopic composition of the elements In Isotopic Analysis: Fundamentals and applications using ICP-MS (1 stedn), Edited by Vanhaecke F, Degryse P. Wiley-VCH GmbH \& Co. KGaA, Weinheim.
[46] Asperger S (2003) Chemical Kinetics and Inorganic Reaction Mechanisms Springer science + Business media, New York.

[47] http://www.eolss.net/sample-chapters/c06/e6-104-01-00.pdf.

[48] Lomas JS, Thorne MP (1982) Structure and isotope effects upon the thermal decomposition of carbamates of highly congested tertiary alcohols. J Chem Soc, Perkin Trans 2221 226.

[49] www.nobelprize.org/nobel_prizes/physics/laureates/2015/adva nced-physicsprize2015. pdf.

[50] Balantekin AB (2013) Neutrinos and rare isotopes Journal of Physics: Conference Series 445012022. 